Revue d'histoire du XIXe siècle

Société d'histoire de la révolution de 1848 et des

révolutions du XIXe siècle

16 | 1998

1848. Un modèle politique à l'épreuve

\title{
Les républicains bleus du Havre sous la Seconde République
}

\author{
Pierre Ardaillou
}

\section{OpenEdition}

\section{Journals}

Electronic version

URL: http://journals.openedition.org/rh19/126

DOI: $10.4000 /$ rh19.126

ISSN: 1777-5329

\section{Publisher}

La Société de 1848

\section{Printed version}

Date of publication: 1 June 1998

ISSN: 1265-1354

Electronic reference

Pierre Ardaillou, "Les républicains bleus du Havre sous la Seconde République », Revue d'histoire du XIXe siècle [Online], 16 | 1998, Online since 10 September 2008, connection on 20 April 2019. URL: http://journals.openedition.org/rh19/126 ; DOI : 10.4000/rh19.126

This text was automatically generated on 20 April 2019

Tous droits réservés 


\title{
Les républicains bleus du Havre sous la Seconde République
}

\author{
Pierre Ardaillou
}

\begin{abstract}
S
(!--resume_anglais--) The historiographic importance given to the party of order and to its struggle with the democrats and the socialist democrats may have hidden a third steam: the moderate republicans. However the "bleu" republicans of Le Havre are a good illustration of the role they played during the Second Republic. In the Norman harbour the year of 1848 was indeed that of the assertion of a liberal political culture embodied by an elite of merchants. They remembered the American example and they knew that the Republic they wished for could peacefully put and end to the era of revolutions. However these republicans' position on the social issue -i.e. the refusal of any sort of reform of labour or education- was to lead them to a relative political failure, namely in front of the threat of a "coup d'État" that a "fussy legalism" could not fight alone.
\end{abstract}

L'importance historiographique accordée au parti de l'ordre et à son conflit avec les démocrates et les démocrates-socialistes a peut-être occulté un troisième courant, celui des républicains modérés. Les républicains " bleus " du Havre sont pourtant une bonne illustration du rôle qu'ils ont pu jouer durant la Seconde République. L'année 1848 fut en effet, dans le port normand, celle de l'affirmation d'une culture politique libérale incarnée le plus souvent par une élite de négociants, marqués par l'exemple des États-Unis et pour lesquels la République à laquelle ils aspiraient pouvait clore, dans l'ordre, l'ère des révolutions. Toutefois la position de ces républicains sur la question sociale - constituée par le refus de toutes réformes à propos du travail ou de l'éducation - allait leur faire connaître un relatif échec politique, notamment face à 
la menace d'un coup d'État " qu'un légalisme pointilleux" ne pouvait seul combattre.(!-resume_anglais--) (!--resume_anglais--) The historiographic importance given to the party of order and to its struggle with the democrats and the socialist democrats may have hidden a third steam: the moderate republicans. However the "bleu" republicans of Le Havre are a good illustration of the role they played during the Second Republic. In the Norman harbour the year of 1848 was indeed that of the assertion of a liberal political culture embodied by an elite of merchants. They remembered the American example and they knew that the Republic they wished for could peacefully put and end to the era of revolutions. However these republicans' position on the social issue -i.e. the refusal of any sort of reform of labour or education- was to lead them to a relative political failure, namely in front of the threat of a "coup d'État" that a "fussy legalism" could not fight alone.

INDEX

Mots-clés: 1848, Le Havre, Seconde République 